\title{
KÓNYA ISTVÁN
}

\section{Az alapvető rendelkezések jelentősége az új büntetőeljárási törvényben}

Továbbra is kúriai szemmel az új büntetőeljárási törvényröl, avagy ami a szeptemberi mondanivalómból kimaradt

Szükség van-e a törvénynek preambulumra, szüksége van-e az ítélőbírónak és általában a büntetőjog alkalmazójának alapelvekre vagy alapvető rendelkezésekre?

Nem idejétmúlt törvényalkotói megoldás-e olyan rendelkezésekkel növelni a törvény terjedelmét, amelyek jól hangzó, szépen megfogalmazott elveket deklarálnak, de normatív tartalmuk közvetlenül nincs, ezáltal gyakorlati jelentőségük megkérdőjelezhető. Ha nem is pontosan ezekkel a szavakkal, de ilyen kérdések az új Be. kodifikációja során bizony felvetődtek. Ezek a dilemmák sem új keletüek, hiszen az 1998. évi XIX. törvény (egyelőre még hatályos Be.) megalkotásánál is szót érdemeltek, és $A$ büntetöeljárási jog címen 2000-ben kiadott, Király Tibor akadémikus neve által fémjelzett egyetemi tankönyv feltette a kérdést: , elavultak-e az alapelvek?"

Az Új magyar büntetöeljárás címmel a Fenyvesi Csaba, Herke Csongor és Tremmel Flórián alkotta jeles szerzőhármas által készített egyetemi tankönyv ${ }^{2}$ ugyancsak tudományos igénnyel foglalkozik az alapelvek jelentöségével, és ennek során egyenesen az „alapelv-infláció” veszélyére hívja fel a figyelmet. ${ }^{3}$

Mindenesetre mindkét jogirodalmi mü az alapelvek megtartásának indokoltsága mellett foglalt állást, nem utolsósorban annak a felfogásnak az alapján, hogy azok az eljárás garanciái közé tartoznak és elhagyásuk a büntetőeljárás tudományának visszafejlődését valósítaná meg.

Király Tibor meghatározása szerint ,,az alapelvek a büntetőeljárási jogban olyan általános tartalmú normák, amelyek jellemzik és meghatározzák a büntetöeljárás rendszerét, müködését, az eljárásban résztvevook jogainak és

\footnotetext{
1 Király Tibor: Büntetőeljárási jog. Osiris Kiadó, Budapest, 2000, 91. o.

2 Fenyvesi Csaba - Herke Csongor - Tremmel Flórián: Új magyar büntetőeljárás. Dialóg Campus Kiadó, Budapest-Pécs, 2004

3 Uo. 4.3. pont, 62. o.
} 
kötelességeinek lényeges elemeit, és arra szolgálnak, hogy irányítsák az egész büntető igazságszolgáltatás müködését. Az alapelvek a büntetőeljárásban normaként jelennek meg, éspedig vagy kiemelt, nevesitett formában (ahogyan az az 1973. és 1998. évi Be.-ben), vagy nevesités nélkül, amikor is a törvény egyes rendelkezéseiböl az alapelvre következtetünk."

A 2017. évi XC. törvény (a továbbiakban: Be.) az 1998. évi XIX. törvényhez (a továbbiakban: korábbi Be.) hasonlóan alapvető rendelkezésekről és nem alapelvekröl szól, jóllehet tartalmilag egyaránt olyan általános szabályokat tartalmaz, amelyek áthatják az egész büntetőeljárást, meghatározzák a rendszerét, és szólnak az eljárásban részt vevők jogainak és kötelességeinek lényeges elemeiröl. A Be. azonban céltudatosan használja az alapvető rendelkezés fogalmat, mert azokat megkülönbözteti az elvektől, hangsúlyozva azok általánosan kötelezö, normatív tartalmát. Ezt a törekvést az alapvető rendelkezések indokolása a következők szerint szemlélteti: , A hazai büntetőeljárási kódexek bevezetö részében megfogalmazott, általános jellegü szabályok rendre igyekeztek az aktuálisan szabályozott büntetöeljárás lényegét kifejezni, egyúttal a jogalkalmazók számára is iránymutatást nyújtani mind a részletszabályok értelmezéséhez, mind a törvényhozó által megkívánt - büntetöeljárási - magatartáshoz. A jogelméletben használt alapelv fogalma, illetve annak is az elv-része a határozott, kötelezö magatartási szabályt tartalmazó jogszabály tekintetében azonban nehezen értelmezhetö. Mindezek mellett a jogelmélet a büntetöeljárás alapelvei közé számos, a büntetöeljárási törvényekben nem szereplö általános tételt is beilleszt, igy az elméleti és jogalkotási fogalom egyébként sem fedné le ugyanazt a kört. Az alapelvek fogalomra ezért indokolt a jogelmélet kizárólagosságát fenntartani és a büntetőeljárási törvényben már a névválasztással tükrözni azt, hogy a jogállami büntetőeljárásnak a jogtudomány által kidolgozott és leirt elvei az Alaptörvény T) cikk (1) bekezdésének is megfelelve általánosan kötelezö, egyúttal alapvetö jelentöségü magatartási szabályok."

A Be. új szabályozásának lényege e szerint az elvek és rendelkezések tartalmi megkülönböztetése, amely szerint az ,alapelv” fogalma a jövőben a jogelmélet kizárólagos használatára marad, és ezzel szemben a jogállami büntetőeljárás igényeit kiszolgálva a jogtudomány által kidolgozott és a joggyakorlat által alkalmazott alapvető jelentőségű elvek az általánosan kötelező magatartási szabályokká lesznek, mert ez felel meg az alaptörvénynek is.

4 Király Tibor: i. m. 81. o. 
Az alapvető rendelkezések célja pedig a jogalkalmazó eligazítása a büntető anyagi jog érvényesítésének törvényes rendjében.

Az 1973. évi I. törvény szabályozása óta eltelt időben immár két törvény kodifikációs folyamatában észlelhető az a tendencia, hogy az eljárási törvények kevesebb alapelvet sorolnak fel, míg velük szemben a tankönyvek és különböző jogirodalmi források különböző szempontok szerint csoportosítva egyre több eljárási elv tárgyalásába bocsátkoznak. Ezt a jelenséget Tremmel Flórián „az alapelv-infláció” veszélyeként nevezte meg.

A Be. indokolása szerint az alapvető rendelkezések kodifikálásának szempontjai a következő megfontoláson alapultak: „Az Alapvető rendelkezések összeállitásánál - a jogalkotásról szóló 2010. évi CXXX. törvény 3. \$-ára is figyelemmel - lényeges szempont volt, hogy a jogelmélet által kidolgozott alapelvek közül a büntetöeljárási törvényben ne szerepeljenek olyan, az Alaptörvényben is rögzitett szervezeti jellegü szabályok, amelyek büntetöeljárásspecifikus vonásokkal nem rendelkeznek, különösen, ha ezen tételek a büntetöügyben eljáró hatóságok, illetve biróságok jogállására vonatkozó sarkalatos - törvényekben is fellelhetöek vagy feltétlen érvényesülésüket maga az eljárási törvény sem biztositja. Szintén kiválasztási szempont volt, hogy a szervezeti jellegü szabályok mellett azon müködési jellegü rendelkezések nevesitése sem szükségszerü, amelyeket szintén az Alaptörvény fektet le, ugyanakkor nem vonatkoznak általánosságban az egész büntetöeljárásra, vagy számos kivételt szükséges biztositani, igy az elv tartalmát az adott eljárási szakaszra vagy jogintézményre vonatkozó részletszabályozás hatékonyabban képes közvetiteni. Az ismertetett szempontoknak megfelelöen az Alapvető rendelkezések között nem szerepel a hatalmi ágak elválasztásából eredö birói függetlenség és a bírák kizárólag törvény alá vetettség, a társas birráskodás, az itélkezésben való társadalmi részvétel, a törvény elötti egyenlöség, a büntetőeljárás törvényességének elve, a biróság eljárásához való jog, a tárgyalás közvetlenségének, nyilvánosságának és szóbeliségének elve, a jogorvoslathoz való jog és a tájékoztatáshoz való jog elve. A jogalkalmazás eligazitása érdekében ugyanakkor a bevezetö részben mindenképp indokolt megjeleniteni a kizárólag a büntetöeljárásra vonatkozó, a kodifikációval kitüzött »eszményi« büntetőeljárás lényegét megragadó alapelveket függetlenül attól, hogy tényleges érvényesülésük esetleg csak az eljárás valamely szakaszában, vagy részletszabályok útján biztositható. E kör meghatározásánál nem befolyásoló tényezö az sem, hogy az ide sorolt alapelvek egy részét az Alaptörvény is tartalmazza, hiszen még az alapvetö rendelkezések közt történö megfogalmazás is szükségszerüen részletezöbb és érdemi, a büntetöeljá- 
rás-specifikus tartalommal tölti ki az alkotmányos követelményeket. Ebböl adódóan a törvény értelmében az Alapvetö rendelkezések közül nem hiányozhat a funkciómegosztás elve, a vádelv, az ártatlanság vélelme, a bizonyitási teher és az in dubio pro reo elve, a védelemhez való jog, a hivatalból való eljárásra vonatkozó szabályok, a büntetöeljárás akadályainak összefoglalása, a büntetöjogi felelösség önálló elbirálásának követelménye, az alapvetö jogok, különösen az emberi méltósághoz, a szabadsághoz és a személyi biztonsághoz való jog védelmének általános kötelezettsége, továbbá az anyanyelv használatának biztositása és ezzel összefüggésben a büntetöeljárás nyelvére vonatkozó alapvetö szabályok."

A jogalkotó az elvek és rendelkezések között - az indokolás idézett tartalma szerint - lényegi megkülönböztetést tesz, és ezzel az alapvető rendelkezések kötelező betartására motiválja a jogalkalmazókat. Az utóbbiak számára ez azt jelenti, hogy a joggyakorlat az eljárási cselekmények elvégzése során az alapvető rendelkezéseket nem sértheti meg. A következetes jogalkalmazói szemlélet jogalkotói elvárása azonban az alapvető rendelkezéseket mégsem ruházza fel olyan normativitással, amely azokat önmagukban alkalmazhatókká tenné. Ugyanakkor hozzá kell tenni, hogy az alapvető rendelkezések megsértése (például: a védelem jogának nem biztosítása, a vádon túlterjeszkedés) semmisségi okot valósíthat meg, és eljárási szabálysértésként hatályon kívül helyezéshez vezethet. Az anyanyelvhasználat jogának csorbítása relatív eljárási szabálysértésként a döntésre kihatás mértékétöl függően járhat következménnyel. Ugyanakkor az ártatlanság vélelme (1. §) elvitathatatlan garanciát jelentő elvének megsértése valamely konkrét ügybeni sérelmét mint hatályon kívül helyezési okot aligha lehet érvényesíteni.

\section{Az ártatlanság vélelmérōl}

Az ártatlanság vélelme változatlan tartalommal alapvető rendelkezése az új büntetőeljárási törvénynek, ugyanazzal a tartalommal, mint az 1998. évi XIX. törvény 7. §-ában. Az új törvény 1 . §-ában csupán az ,ügydöntő határozat" pontosítás tekinthető nóvumnak, és változott a mondat szórendje, e körülmények említésre sem érdemesek. Ennek az alapvető rendelkezésnek a megszövegezéséről is folyt vita a kodifikációs bizottságban, és jóllehet több változat is elkészült ennek a klasszikus vélelemnek az újraszövegezésére, a szakmai testület belátta végül, hogy a lényeget illetően a hatályos Be. 7. §ában megállapítottnál jobbat nem lehet kitalálni. Nem is volt indokolt, mert 
azok a fogalmak, amelyek értelmezési problémától mentesek, az ítélkezési gyakorlat általánosan elfogadott (rutinos) részévé váltak, azokat nem indokolt megbolygatni.

Mindamellett az ártatlanság vélelmével kapcsolatban felelevenedett az a vita, amely nemcsak a szakma képviselöit, de a közvéleményt is foglalkoztatja, ami kérdésként abban foglalható össze, hogy kit köt az ártatlanság vélelme.

Az uralkodó álláspont szerint az ártatlanság vélelmének kizárólag a büntetőeljárásban van jelentősége, mert ez nem egyéb, mint egy bizonyítási szabály, egy megdönthető vélelem, s az eljárás célja tulajdonképpen az, hogy a büntetőigényt érvényesítő közvádló e vélelmet megdöntve meggyőzze a bíróságot arról, hogy a terhelt bünös, s vele szemben büntetést kell kiszabni. A vitatkozó másik álláspont elfogadja ennek az álláspontnak ekként összefoglalt lényegét, de továbbmegy, és az ártatlanság vélelmét más jogviszonyokban is elvárhatónak, sőt számon kérhetőnek tekinti. E szerint az ártatlanság vélelmét nemcsak a hatóságoknak, hanem másoknak is illik tiszteletben tartaniuk, így különösen a tömegtájékoztatási eszközöknek. Mást nem bünösnek tekinteni ugyanis része az ember társadalmi megbecsülésének.

Mivel az ártatlanság vélelmét az alaptörvény Szabadság és felelösség címü részében a XXVIII. cikk (2) bekezdésében deklarálja, az utóbbi álláspontot sem tartom feltétlenül elvetendőnek. Mindemellett indokoltnak tartom a témával kapcsolatban Király Tibor következő álláspontját idézni: ,, Kit köt az ártatlanság vélelme? Az ártatlanság vélelme hatókörének nem elhanyagolható lényeges kérdése: kit is kötelez a törvény által megkivánt magatartásra. Nincs kétség afelöl, hogy az ártatlanság vélelme a büntetőeljárásra vonatkozó norma, tehát az eljárás azon alanyait köti, akik a gyanúsitott, vádlott fölött valaminö hatalmat gyakorolhatnak. Az ártatlanság vélelme kötelezi a birót - és ez felel meg a strasbourgi Emberi Jogok Bírósága gyakorlatának. A bíró számára az ártatlanság vélelme nem azt jelenti, hogy hinnie kell az ártatlanságban, hanem hogy elfogulatlanul kell a pert vezetnie. A kontinentális rendszerü eljárásokban, ahol is a kihallgatást a biró végzi, nem azt a feltételezést kell stílusával, magatartásával sugallnia, hogy a vádlott bünös, hanem azt, hogy megvizsgálja: tényleg ártatlan, vagy netán bünös-e a vádlott. [...] A nyomozó és az ügyész az ártatlanság vélelmét másképp éli meg, mint a biró. A törvény tölük is megköveteli az elfogulatlanságot - nem lehet perben, haragban vagy rokonságban a gyanúsitottal -, de azt a fajta pártatlanságot az ügyben, mint a birótól, nem várja el. Az ügyésztöl a vádemelésben éppen a vádlott bünösségéröl való meggyözödése kérhető számon, illetve 
a nyomozótól (vizsgálótól) az elszántság a bünös felkutatására. Tölük is megköveteli azonban a törvény, hogy a terhelö és mentö, valamint a büntetöjogi felelösséget súlyositó és enyhitö körülményeket figyelembe vegyék. Reájuk tehát az ártatlanság vélelméböl igazán a bizonyitási teher hárul, és az ügy sokoldalú, minden irányú felderitésének a kötelessége. ",

Az ártatlanság vélelme - mint nem bünösségi vélelem - bizonyítási szabályként arra kötelezi elsősorban a közvádlót, hogy a vélelem megdöntése érdekében minden törvényes bizonyítási eszközt használjon fel, és - a hatályos törvényi szabályozással teljesen egyezően (hacsak a törvény eltéröen nem rendelkezik) - a terhelt beismerése esetén is meg kell szerezni az egyéb bizonyítékokat [183. § (4) bekezdés].

A kötelezettség tehát eljárási parancs, a tényállás-felderítési kötelezettség megalapozott teljesítésének félre nem tehető igénye. Számos esetben a szabály azonban illuzórikussá válik. A tetten ért és elfogott elkövetőt „ártatlannak" tekinteni, saját észlelésünknek, azon alapuló meggyőződésünknek ellentmondó követelmény valójában formaság (például a szobatársát baltával lefejező és véres tettét büszkén vállaló tettest nem bünösnek tekinteni - az említett bizonyítási szabály betartásán túlmenően -, a józan ésszel lenne ellentétes).

A kérdés eldöntése differenciáltabb válaszadással lehetséges csak. Minden eset, majd ügy más és más. Sokszor - a látszat ellenére - nem magától értődő, nem egyértelmü, és helyük van a kételyeknek. A büntetőeljárásban ezért mindig szigorúan betartandó, garanciális követelmény.

Ha megengedhetőnek tekintjük, hogy a büntetőeljárási jogviszonyon kívül is hatása legyen, mert a nem bünösség feltételezése része az ember társadalmi megbecsülésének, akkor már el is jutottunk a büntető anyagi jogi megközelítéshez, amely érvként hozható fel ennek az álláspontnak az igazolására. A rágalmazás (Btk. 226. §) jogi tárgya az emberi becsület, amely mint büntetőjogi védelemben részesülö jogi tárgy két elemböl tevődik össze: egyrészt a társadalmi megbecsülést, másrészt az emberi méltóságot foglalja magában. A társadalmi megbecsülés pedig az ,emberröl, egyéni sajátosságairól, tulajdonságairól, a magatartásáról, személyes értékeirōl a környezetben kialakult társadalmi értékitéletet jelenti; az emberi méltóság pedig az egyénnek azt az igényét fejezi ki, hogy olyan elbírálásban részesitsék, ami a társadalomban kialakult érintkezési forma minimális követelményeinek megfelel". ${ }^{6}$

5 Uo. 123. o.

6 Kónya István: Magyar Büntetőjog Kommentár a gyakorlat számára. HVG-ORAC, Budapest, 2017, 868. o. 
Az ártatlanság vélelme ekként egy büntetőjogilag oltalmazott jogi tárgy immanens alkotórésze, amelynek tiszteletben tartása mindenkitől elvárható. Tehát biztos ténybeli alap híján senki nem kiáltható ki bünösnek, mert ez már túlmegy a véleménynyilvánítás szabadságának keretein. Ha például egy köztudomásúan éppen folyamatban levő büntetöüggyel kapcsolatban a nagy nyilvánosság előtt valakiről azt állítják, hogy a tárgyalt ügyben vádban ténylegesen felhozott és a média által visszatérően ismertetett büncselekmény-sorozat bünsegéde, akkor - ha ez a tényállítás valótlan - alkalmas lehet a hírbe hozott személy becsületének csorbítására. Ha tehát az ártatlanság vélelmét az ember társadalmi megbecsüléséhez füződő követelményként fogom fel, akkor annak nemcsak a büntetőeljárási jogviszonyokban, a bizonyítás szabályaiban, garanciájában van jelentősége, hanem a közéletben is. Gondoljunk csak arra, hogy egy-egy olyan büncselekmény kapcsán, amely „nagy port ver fel" és a közvéleményt fokozottan foglalkoztatja, a sajtó, rádió, a televízió milyen gyorsan „meghozza” a maga ítéletét, ami később nem feltétlenül lesz azonos a bíróság ügydöntő határozatával. Az ilyen ellentmondás pedig azzal a következménnyel jár, hogy a közvélemény értetlenül fogadja a bíróság ítéletét, mert nem felel meg annak az elvárásnak, amit a sajtó, televízió stb. hónapokon vagy éveken át tartó rendszeres befolyásolásával a közönségben felépített. A közhangulat szükségtelen felborzolása elkerülhető lenne, ha a tömegtájékoztatás szereplöi maguk is tiszteletben tartanák az ártatlanság vélelmét, még ha nem is oly kötelező erővel, miként az a büntetőügyben eljáró hatóságokat terheli.

Az ártatlanság vélelméről az új törvény olvasásakor eszembe jutott gondolatokat hadd zárjam Király Tibor vitathatatlan igazságú álláspontjával: , $A z$ ártatlanság vélelme, hisszük nem a bünösök, hanem az ártatlanok menedéke [...] nem szabad, hogy egyfajta üres szólam legyen egy olyan társadalomban, amelyben antagonisztikus ellentétek vannak."

\section{Az alapvető jogok védelméről}

Új alapvető rendelkezés, amely az ember sérthetetlen és elidegeníthetetlen alapvető jogainak tiszteletben tartásán alapul, és az állam által védendő kötelezettségeként, nevesített formában gazdagítja a büntetőeljárás ,alapelveit”.

7 Belovics Ervin - Tóth Mihály: Büntető eljárásjog. HVG-ORAC, Budapest, 2017, 55. o. 
A sérthetetlen és elidegeníthetetlen (az emberi mivoltból következő) jogok közül a törvény külön kiemeli az emberi méltósághoz, a szabadsághoz és személyi biztonsághoz füződő jogokat. E példálózó kiemelés nem véletlen, hiszen könnyen belátható, hogy éppen ezek a jogosultságok azok, amelyeket a büntetőeljárás a leginkább érinthet, mert a büntetőjog az, amely a legmélyrehatóbb beavatkozásra képes az egyén életébe, egzisztenciájába.

Az alaptörvény a biztosított jogok közül az emberi méltóságot, valamint a szabadsághoz és személyi biztonsághoz füződő jogokat emeli ki és részesíti védelemben. A törvény nem csupán a terhelt, hanem - szóhasználatából következően - a büntetőeljárás valamennyi résztvevője számára megkívánja e jogok tiszteletben tartását. A tárgyalt szakaszban nevesített alapjogok kiemelése és a védelmük alapvető rendelkezések körében történő elhelyezése a büntetőeljárási jogviszony természetével magyarázható. A büntetőeljárásban az állam büntetőigényének érvényesítését rendészeti kényszer alkalmazhatósága biztosítja, amely érthetően és elsősorban az említett három alapjog korlátozását valósíthatja meg.

\section{A védelem jogáról}

Ez az alapvető rendelkezés ugyanilyen megnevezéssel 5. §-ként van szabályozva a hatályos Be.-ben. Az új törvény megőrzi a hatályos Be. alapvető rendelkezésének tartalmi követelményeit, de tovább is fejleszti őket, és bővíti a védelemhez való jog tartalmát, sőt kimondottan erősíti, amikor minőségi követelményt állapít meg a védelem ellátását illetően, midőn az (1) bekezdésében meghatározza, hogy a terheltnek a büntetőeljárás minden szakaszában hatékony védelemhez van joga. E fontos értékkikötés kétségtelenül a terhelt érdekét szolgálja, de veszélyt is rejt magában, amennyiben igen viszonylagos értékü a kívánalom attól függően, hogy a terhelt mennyire lesz elégedett ügyének elbírálásával. Tudniillik, akár alkotmányjogi panaszokat alapozhat majd a marasztaló ítélettel elégedetlen terhelt annak sérelmezésére, hogy alkotmányos alapjoga csorbult, amikor az eljárásban a védelmét nem látták el kellő hatékonysággal, mert elítélték, holott ő mindig tagadta a terhére felhozott vádakat.

A terhelt eljárási pozíciójának megerősítését szolgálja az új megoldás is, hogy a terheltet mentő, illetve a felelősségét enyhítő körülmények hivatalból történő figyelembevételét a törvény a bíróság, az ügyészség és a nyomozó hatóság számára alapvető rendelkezésként írja elő. 


\section{A büntetőeljárás alapja és akadályai alapvető rendelkezésről}

Ez az alapvető rendelkezés a hatályos Be. 6. §-át váltja fel, amely a hivatalból való eljárás, a büntetőeljárás megindítása és a büntetőeljárás akadályai címet viselte. A változásra az új törvény már a 4 . § címében utal, amely az elözőhöz képest „a büntetőeljárás alapja és akadályai” elnevezést kapta.

Ez a kodifikációs megoldás az állam büntetőigényének közvádra történő érvényesítésével összefüggő officialitást a helyére teszi, és világos helyzetet teremt. Ugyanis a korábbi Be. eljárási rendje is valójában ennek felelt meg, jóllehet az alapvető rendelkezések sorában a 6 . § hivatalból való eljárásról, a büntetőeljárás megindításáról és a büntetőeljárás akadályairól rendelkezett, és a korábbi Be. 6 . § (1) bekezdése ebben a bíróságot is a hivatalbólisággal terhelt alanyként állapította meg. E korábbi szabályozást Király Tibor okkal ítélte tévesnek a következők szerint: „A Be. 6. § (1) bekezdésében az officialitás követelményét merö félreértésböl a bíróságra is kiterjesztette. A biróság ugyanis hivatalból eljárást nem indit, hanem csak vád alapján jár el, és a feladata a vádról való döntéssel, és nem pedig az eljárás lefolytatásának kötelességével jellemezhetö. Ahogy már volt róla szó, az officialitás mint a magánbünüldözés, a magánvád ellentétje alakult ki, és mint ilyent kell ma is kezelni. Törvényhozói tévedés tehát a Be. 6. § (1) bekezdésében az utalás a bíróság kötelességére. " ${ }^{8}$ Ezt a tévedést a kodifikáció most kijavította.

\section{Az eljárási feladatok megoszlásáról}

Az eljárási feladatok megoszlása nem más, mint a büntetőeljáráson belüli következetes munkamegosztás rendje, amely szerint a vádlói, a védői és az ítélkező funkciók nem cserélődhetnek fel és nem keveredhetnek. A vádló nem ítélkezhet, az ítélő bíró nem veheti át a vádló szerepét és nem is pótolhatja a vád esetleges hiányosságait, de ítéletet hozni vád nélkül nem lehet.

Az eljárási feladatok megoszlásának elvét a hatályos törvény 1 . §-a az új törvénnyel azonos tartalommal deklarálja. Az új törvény nem változtatta meg a rendelkezés tartalmát, de a büntetőeljárás különböző szakaszainak szabályozásával az egyértelmübb felelősségi teher elöírásánál a funkciómegosztás következetesebb érvényesítésére törekszik. Ennek megjelenítése annak egyértel-

8 Király Tibor: i. m. 108. o. 
mü rögzítése, hogy a hivatalból történő bizonyítás megszünik, a vád bizonyítása nem a bíróság, hanem - bevallott jogalkotói szándék szerint - egyértelmüen a vádló feladata és felelőssége. A funkciómegosztásra épülő szemlélet a feladatokat azáltal is markánsabban határolja el egymástól, hogy a védelemtől kifejezetten a bírósági eljáráshoz méltó felkészültséget követel meg.

A bizonyítás rendjén belül ezt a követelményt szolgálja a 164. § mindhárom bekezdése:

„(1) A vád bizonyitásához szükséges tények feltárása, az alátámasztásukra szolgáló bizonyitási eszközök rendelkezésre bocsátása, illetve beszerzésének inditványozása a vádlót terheli.

(2) A bíróság a tényállás tisztázása során bizonyitékot indítvány alapján szerez be.

(3) Inditvány hiányában a bíróság bizonyiték beszerzésére és megvizsgálására nem köteles."

Ha a (2) bekezdésnél a jogalkotó megáll, egyértelmủ szabályozást ad, ám ehhez képest a (3) bekezdés elbizonytalanít, és az előző bekezdés kijelentő módjához képest nehezen értelmezhetö. A (2) bekezdés kijelentő módjában fogalmazott rendelkezése ugyanis arra enged következtetni, hogy attól eltérésnek nincs helye.

Az alapvető rendelkezés célja, hogy jellemezze, meghatározza az egész büntetőeljárás rendszerét, müködését. A szóban lévő alapvető rendelkezés felülbírálati konzekvenciáját a megalapozatlanságért viselt felelősség körén belül az 592. § (4) bekezdése vonja le azáltal, hogy ,ha a megalapozatlanság nyilvánvalóan a 164. § (1) bekezdésében foglalt kötelezettség elmulasztására vezethetö vissza, a megalapozatlanság következményei nem alkalmazhatók".

Utóbbi rendelkezés erejét, hatékonyságát azonban gyengíti, hogy a „nyilvánvalósággal" szemben a felelősség alól menekülési utat elégséges módon biztosítja a vádló számára önmagában (minden tényleges eljárási cselekmény elvégzése nélkül) már az, ha a vád bizonyításához szükséges bizonyítási eszközök beszerzését indítványozza.

\section{Az ítélkezés alapja és vádhoz kötöttségről}

A leglényegesebb változás, hogy a tárgyalt alapvető rendelkezés elhagyta a törvényes vád korábbi Be. 2. §-ának (2) bekezdésében adott, sokszor értelmezett és néha vitatott definícióját. 
A vádirat törvényes elemeit azonban a Be. 422. § (1) bekezdése tartalmazza. A vádirat hiányosságának pótlására pedig a 493. § ad felhatalmazást a bíróságnak, hogy hivatalból vagy indítványra a hiányok megjelölése mellett végzésben hívja fel az ügyészséget a vádirat hiányosságainak pótlására. Az ügyészség a vádirat hiányosságait az azok pótlására felhívást tartalmazó végzés kézhezvételétől számított két hónapon belül pótolhatja [493. § (2) bek.]. A bírósági eljárás struktúrájának átalakítása, illetve az előkészítő ülés szerepének megnövelése miatt a hivatkozott paragrafus (4) bekezdése ugyanerre az előkészítö ülés megkezdése előtt is feljogosítja a bíróságot.

Az 567. § (2) bekezdésének d) pontja pedig arra kötelezi a bíróságot, hogy végzésével megszüntesse az eljárást, ha a vádirat nem vagy hiányosan tartalmazza a 422. § (1) bekezdésében írt törvényes elemeket, és emiatt a vád érdemi elbírálásra alkalmatlan.

A bíróságra a funkciómegosztás elve szerint az ítélkezés hárul, ami nem más, mint a döntés az érvényesített büntetőigényröl. Ez tipikusan a közvádló által előterjesztett büntetőigény, amely az állam büntetőigényének érvényesítését valósítja meg. A vádat a bíróság ügydöntő határozatában köteles elbírálni. A törvényes vád fogalmának normatív meg nem jelenítése nem változtat azon a követelményen, hogy alakilag és tartalmilag törvényesnek kell lennie, azaz az arra jogosulttól kell származnia (közvádló, magánvádló, pótmagánvádló), és olyan történést (történeti tényállást) írjon le, amely büntetőtörvénybe ütközik, azaz kimeríti valamely különös részi tényállás elemeit. A vád törvényes elemeit a 422. § (1) bekezdés a)-d) pontjáig terjedő felsorolás határozza meg. A vádban leírt történeti tényállást kell elbírálni, azaz dönteni arról, hogy amit az tartalmaz, a valóságban megtörtént-e, az követte-e el, akit ezzel megvádoltak, és a döntés korlátja az, hogy a bíróság csak a leírt történést vizsgálhatja, annál többről (másról) nem ítélkezhet. Ez jelenti a vád kimerítését. Ennek teljesnek, maradéktalannak kell lennie.

\section{A bizonyítás alapvetéseiről}

A bizonyítás alapvetései címmel a Be. új alapvető rendelkezést kodifikált, amely azonban tartalmilag azonos a korábbi Be. 4. §-ában bizonyítási teherként megfogalmazott alapvető rendelkezéssel és a tartalmában az ártatlanság vélelméből következő önvádra kötelezés tilalmával. A 7. § (4) bekezdése pedig az in dubio pro reo klasszikus elvét tartalmazza, amelyet a korábbi eljárási törvény a bizonyítási teherről szóló 4 . § (2) bekezdésében azonos tar- 
talommal írt elő. Az (5) bekezdés pedig a büntetőjogi felelősség önálló elbírálását emelte a bizonyítás alapvetései közé, amelyet a gyakorlat ugyancsak ismer, a korábbi Be. 10. §-ából.

Az alapvető rendelkezések bizonyítási alapvetésül, összeállított „gyüjteményes" rendelkezése egy tekintetben gazdagodott lényeges többlettel, éspedig a (2) bekezdéssel, amely kimondja, hogy a terhelt nem kötelezhető ártatlanságának bizonyítására.

A bizonyításra vonatkozó új korlát szerint a terhelt nem kötelezhetỏ ártatlanságának bizonyítására, nyilvánvalóan következik a (3) bekezdésben megtartott önvádra kötelezés tilalmából, de önálló tilalomként történő megfogalmazása a gyakorlatban időnként előforduló bizonyítási - és különösen indokolási - aránytévesztések miatt feleslegesnek nem tekinthető. Ezen a téren szemlélet- és tudatváltozáson kell átmennie minden büntetőeljárással foglalkozó hatóságnak.

\section{A büntetőeljárás nyelve és nyelvhasználat jogáról}

A 8. § (1) bekezdése szerint a büntetőeljárás nyelve a magyar, azaz az eljárás résztvevői mind szóban, mind írásban a magyar nyelvet használják, magyarul kell megszövegezni a jegyzőkönyveket és a határozatokat.

A Be. a korábbi eljárási törvény ugyanezen alapvető rendelkezésének szabályozásától kissé eltérve a korábbi sorrendet felcserélve annak deklarálása után, hogy a büntetőeljárás nyelve a magyar, már az (1) bekezdésben kimondja, hogy a Magyarországon élö, a törvényben elismert nemzetiségek tagjai a büntetőeljárásban a nemzetiségi anyanyelvüket használhatják. Ezáltal a nemzetiségek tagjainak anyanyelv-használati joga a büntetőeljárás magyar nyelvüségének fő szabályával egy sorba került.

Fontos azonban rámutatni, hogy a visszaélés lehetőségének kizárása érdekében ,, a Be. - a korábbi szabályozással szemben - nem a nemzetiségi nyelv, hanem a nemzetiségi anyanyelv használatának jogát garantálja; a Magyarországi nemzetiség tagja tehát akkor használhatja a büntetöeljárásban a nemzetisége nyelvét, ha az - legalábbis a magyarral párhuzamosan-egyúttal az anyanyelve is"."

9 Az Országos Bírósági Hivatal koordinálásával a 2017. évi XC. törvény (új Be.) kapcsán készülő kézikönyv tervezetéből. 
Ebből már következik az a tény, amelyet a (2) bekezdés megállapít, hogy a magyar nyelv nem ismerése miatt senkit nem érhet hátrány. Az új (1) és (2) bekezdés tehát tartalmi azonosság mellett hangsúlybéli különbséget hoz létre az előző törvényhez képest, a garanciális tartalom erősítésének felismerhető szándékával.

A büntetőeljárási törvény a magyar jelnyelvről és a magyar jelnyelv használatáról szóló 2009. évi CXXV. törvény rendelkezéseinek és a fogyatékossággal élő személyek jogairól szóló egyezmény aláirása és ratifikációja tárgyában hozott 2007. évi XCII. törvénynek megfelelően a nyelv fogalmába sorolja a jelnyelvet és a nem beszélt nyelv egyéb formáit is. A hivatkozott egyezmény 2. cikke arra kötelez, hogy a részes államok minden szükséges intézkedést megtegyenek annak érdekében, hogy az állam hozzáférést nyújtson a szakképzett jelnyelvi tolmácsokhoz. Az egyezmény 21. cikke deklarálja a fogyatékos emberek információhoz való hozzáférésének jogát, és célként tüzte ki azt, hogy a fogyatékos, hallássérült emberek hivatali érintkezése során a támogatott jelnyelv elfogadott legyen. A 2009. évi CXXV. törvény indokolása szerint: ,, A jelnyelvi tolmácsszolgáltatáshoz való jog biztositása különösen fontos a hatósági eljárások során. A jelenleg is müködö, de sem tartalmilag, sem terminológiailag nem egységesen szabályozott, széttagolt gyakorlat egységesitése érdekében szükségessé vált egyes eljárási jogszabályok módositása. A törvény ennek megfelelöen a közigazgatási hatósági, a szabálysértési, a büntetö, a polgári és egyes közjegyzöi eljárások esetében azonos szabályok szerint teszi kötelezövé a jelnyelvi tolmács kirendelését. A jelnyelvi tolmácsolás a hallássérült és a siketvak emberek számára a (köz)szolgáltatásokhoz való egyenlö esélyü hozzáférés megteremtésének egyik legföbb eszköze, amelyet a -fentieken túl - a fogyatékos személyek jogairól és esélyegyenlöségük biztositásáról szóló 1998. évi XXVI. törvény is elöir."

A Be. a korábbi eljárási törvénynek a tolmácsra vonatkozó rendelkezések körében már bevezetett jelnyelvi tolmács közremüködésével kapcsolatos szabályozása megörzése mellett az alapvető rendelkezések körében ismerte el a fogyatékos, hallássérült, illetőleg siketvak személyek nyelvi jogainak egyenrangúságát, és az egész büntetőeljárásra érvényes követelményként írta elő a jelnyelv-használati kommunikáció biztosításának garanciáját. A jelnyelvi tolmácsolást végzők nevét a Budapest Főváros Kormányhivatala által vezetett Jelnyelvi Tolmácsok Országos Névjegyzéke tartalmazza. 


\section{A törvény hatályáról}

A törvényhelyhez füzött indokolás szerint: ,, a jogalkotás szakmai követelményei alapján, különösen a jogszabályszerkesztésről szóló 62/2009. (XII. 14.) IRM rendelet 60. $\S$ (1) bekezdés a) pontjára figyelemmel az Alapvetö rendelkezések között kizárólag a törvény tárgyi hatálya szerepel, az idöbeli hatállyal összefüggö szabályokat a törvény a korábbi Be. megoldásával ellentétben az Átmeneti rendelkezések között helyezi el”.

Király Tibor szerint a büntetőeljárás közvetlen céljai évszázadok óta nem változtak. Ezek a célok a büncselekmények és elkövetőik felderítése, bíróság elé állítása, felelősségre vonása és megbüntetése. A büntetőeljárás a büntetőjog érvényesítésének egyetlen útja. A büntetöjog parancsa, amely szerint a bűncselekmény elkövetőjét érdeme szerint büntetőjogi szankcióval kell sújtani, egyedül és kizárólag a büntetőeljárásban valósítható meg. A 2017. évi XC. törvény célját a törvény preambuluma tartalmazza, amely a büncselekmények elkövetőinek észszerủ határidőn belül lefolytatott eljárásban történő felelősségre vonását határozta meg, ,, szem elött tartva az igazság megállapitásának igényét".

A törvényhez füzött indokolás bevezető része egy igen lényeges megállapítást és deklarációt tartalmaz, e szerint „, a magyar igazságszeretö és igazságkeresö nép, az anyagi igazságon alapuló büntetőjogi felelösségre vonás pedig alapértéke a jelenleg hatályos eljárási törvényünknek”. Király Tibor szerint a büntetőeljárás feladata „az igazság megállapitásának jogi kötelezettsége".

Az általános indokolás az új büntetőeljárási törvény megalkotását - egyebek között, de nyomatékos hangsúllyal - azért találta szükségesnek, mert „, szükségszerü, hogy az állam minden eddiginél jobban kifejezze: a sérelmet szenvedett fél mellé áll, és a büntetöeljárás lefolytatását érdemben elösegitökre is partnerként tekint. A büntetöeljárások gyakorlatában nyilvánvalóvá kell válnia, hogy a büncselekmények elkövetése nem kifizetödö tevékenység, a bünös úton elért gazdagodás nem tartható meg. ” Az eljárási törvény megalkotásának szükségességét igazoló célkitüzések igazságról és igazságszeretetről, a bünözés hiábavalóságát nyilvánvalóvá tévő büntetőeljárásról szólnak, annak ígéretével, hogy az állam a sérelmet szenvedett fél mellé áll, a törvény pedig különös hangsúlyt helyez a büncselekmények áldozatainak védelmére. Ezeknek a céloknak a megvalósítása, a sérelmet szenvedőknek tett ígéret betartása a közhatalom, szükebb értelemben pedig az igazságszolgáltatás iránti közbizalom nélkülözhetetlen feltételei. 
A büntetőjog-alkalmazóknak mindennapi munkájukban állandóan szem elött kell tartaniuk ezeket a célkitüzéseket, cselekedjenek az eljárás korábbi vagy későbbi szakaszában, teljesítsék hivatásukat a bünüldözés-igazságszolgáltatás bármely szintjén. Az alapvető rendelkezések általánosan kötelező magatartási szabályként ennek érdekében hatják át az eljárás egész folyamát, minden állomását. Az állam más hatalmi ágainak pedig a maguk eszközeivel elö kell segíteniük, hogy a harmadik államhatalmi ág rendeltetését betölthesse a tisztességes polgár nyugalma, biztonsága és igazságszolgáltatás iránti bizalmának megerősítése és megőrzése érdekében. 